\title{
Impresos que interpelan la mirada Acerca de la cultura gráfica
}

\section{SANDRASZIR}

sandraszir23@gmail.com - Editora Invitada / Universidad de Buenos Aires (UBA), Universidad Nacional de San Martín (UNSAM) y Centro Argentino de Investigadores de Arte (CAIA), Argentina.

La historia de las ediciones ilustradas representa un amplio campo de estudio dentro de la cultura impresa que, aunque despliega una serie de temas y problemas singulares, involucra una pluralidad de aspectos a estudiar. Desde una perspectiva histórico cultural, dado los dominios que abarca y la multiplicidad de perspectivas que admite, demanda una convergencia interdisciplinar donde la historia del libro, la historia del arte y de la comunicación visual, el diseño gráfico, la bibliografía y la sociología cultural son algunas de las aproximaciones posibles.

El campo de objetos que considera se remonta al momento de aparición de la imprenta, en los albores de la cultura impresa, cuando las imágenes reproducidas a partir de distintos medios tecnológicos se emplazaron en el soporte de la página cumpliendo muy diversas funciones. El aporte de la historia del libro implica considerar la cultura impresa como un conjunto de objetos -libros, publicaciones periódicas, folletos y otros- a la vez que, a sus procesos de producción, circuitos y modos de circulación y diseminación de lo escrito, conjuntamente con los usos de lo impreso y las prácticas de lectura (Chartier, 1987; Eisenstein, 2010). Este campo disciplinar brinda pues, una cantera continua de herramientas y ofrece un conjunto activo que permite trazar relaciones entre los enfoques eruditos y técnicos de una bibliografía material más descriptiva (Gaskell, 1998), o los métodos y las aproximaciones de la historia social (el mundo social y técnico de la imprenta, sus prácticas y modos de hacer) ${ }^{1}$, y la sociología de la cultura (las variables de la difusión y el

1 Entre una amplia y provechosa bibliografía que contempla estos aspectos pueden verse los cuatro tomos de la Histoire de l’édition française (Chartier y Martin, 1989-1991). 
consumo) $)^{2}$. Puede mencionarse asimismo a la paleografía cultural que analiza los gestos y prácticas de la escritura en sus contextos técnicos y culturales. Armando Petrucci (1999) observa el mundo de los tipógrafos, impresores, ilustradores, grabadores, y otros productores, a menudo actores anónimos, y destaca su rol y sus competencias técnicas y visuales que devienen huellas en el impreso.

Pero en el encuentro de la cultura impresa con la cultura de la imagen, accedemos a una complejidad significativa ya que el análisis de las imágenes devuelve en parte la interdisciplinariedad a una necesidad de especificidad disciplinar. Sin embargo, la imagen impresa en la mayoría de los casos está ligada a lo escrito, comparte con él el espacio de la página o del impreso. Pero del mismo modo que históricamente las tecnologías de reproducción de las imágenes no fueron siempre compatibles con las de impresión de los textos ${ }^{3}$, el estudio conjunto de la materialidad y visualidad de la imagen junto con el de los discursos ha sido problemático. Con auxilio de la semiótica, las metodologías propuestas deben ser contrastadas con las particularidades históricas que señalan una variedad de encuentros y de sentidos entre imagen y texto (Le Men, 1995 y 2002; Nicolajeva y Scott, 2006).

Pero esta cultura impresa en relación con la de la imagen devino más gráfica en el siglo XIX (Twyman, 1994) al momento en que los rasgos no verbales, las características que apelan esencialmente a ser vistas, se tornaron más frecuentes. Estas cualidades visuales, portan un sentido en sí mismas, agregan algo a nuestra comprensión o sugieren una dimensión extra de significado o una vía alternativa para su comprensión a través de la mirada.

En efecto, a partir del siglo XIX, la invención de nuevas tecnologías de reproducción de imágenes y el desarrollo de otras ya existentes, permitieron que la capacidad de producción se multiplicara, generando cambios en los costos y tiempos de fabricación y aumentando la puesta en circulación de ejemplares ilustrados. Un orden social diferente, el acceso a la alfabetización por parte de públicos más amplios, así como otros factores políticos, sociales y culturales y la ampliación de los usos de la imagen, produjo una cultura visual impresa o cultura gráfica, de significación inédita en términos cuantitativos y cualitativos.

Estos objetos gráficos, a menudo de carácter efímero y desatendidos, y otras veces de una amplia circulación y vasta presencia en colecciones públicas y privadas, ofrecen un testimonio acerca de la importancia cultural que han tenido como modo de comunicación en diversos campos sociales, como el político, científico o pedagógico. Con su extensa historia, la página ilustrada

2 Un ejemplo lo constituye Robert Darnton (1990; 2006).

3 Se debe a que los sistemas de impresión corresponden a sistemas en relieve (los tipos móviles y la xilografía, de matriz de madera), planos (litografía, matriz de piedra) o en hueco (grabado en metal). La impresión de tipos móviles es por lo tanto compatible sólo con la xilografía (y con el fotograbado desde fines del siglo XIX). El huecograbado y la litografía no pueden imprimirse conjuntamente en la misma página con los textos. 
impresa en sus múltiples soportes ha conocido un acceso y masividad amplia y creciente, desafiada en la actualidad por la tecnología digital. Ha experimentado a su vez transformaciones que van de lo tecnológico a lo visual y al diseño y marcan una gran cantidad de estrategias y modalidades de relación entre texto e imagen, de utilización del color y de variados recursos estéticos.

En América Latina, a pesar de su presencia en la vida cotidiana de gran cantidad de sociedades, encontramos numerosas colecciones que esperan ser estudiadas en lo que respecta a sus tradiciones gráficas, práctica profesional de producción, diseño, modalidades visuales, tecnologías de reproducción y sus modos de apropiación por parte de los públicos consumidores. Aunque resulta un área de investigación de larga data, se encuentra en expansión y en búsqueda de su especificidad para definir sus preguntas y problemas y vincular los objetos, con sus procesos y prácticas de producción, sus usos y funciones, sus sentidos sociales y culturales.

Sería parcial e injusto trazar un estado de la cuestión de los estudios de cultura gráfica en la región de América Latina, podría afirmarse que a pesar de la enorme diversidad de escenarios y situaciones pueden generalizarse ciertos rasgos comunes. La imagen fue en ocasiones un recurso escaso, de usos plurales, de penosa ejecución, frecuentemente resuelta rápidamente y a menudo de carácter humilde, con la que los productores aspiraban alcanzar públicos más amplios, movidos talvez por la atracción delo visual. Se presenta regularmente una tensión entre los textos y las imágenes, por las modalidades de producción en las cuales los modos de procurarse los originales eran muy variados, por momentos se interpreta un signo visual, nacionalizando una representación visual tomada de una publicación europea.

Los artículos aquí presentados aportan un entrecruzamiento de miradas con las cuales manifiestan claramente la densidad de sentidos sociales que los impresos ilustrados en México, Brasil, Argentina, al igual que en otros países de la región -ya sean libros o publicaciones periódicas- pueden abrigar y revelar. Estos libros, diarios o revistas, de carácter científico, político o cultural exponen además su perfil de objeto material cuyas particularidades físicas y visuales exhiben nuevas significaciones.

En "Imagens para instruir. Estudo das estampas que compõem a edição portuguesa do poema As Plantas de Ricardo de Castel", Fátima Medeiros de Souza describe a través del análisis de un libro ilustrado del siglo XVIII editado en Portugal, el rol que las imágenes cumplieron en la difusión de conocimientos y prácticas científicas. La cultura científica difundida por los intelectuales luso brasileños hizo uso del recurso de las imágenes junto con los textos para transmitir información acerca del conocimiento natural y de prácticas agrícolas, de acuerdo con modelos enciclopedistas. El grabado en metal, utilizado en ese periodo como un medio apto de difusión de saberes y valores en el contexto de la cultura ilustrada, potenciada por viajes explo- 
ratorios y con impulsos políticos y económicos, tiñe además con un carácter didáctico al libro analizado. Un libro de poesía y ciencia, en formato portátil y económico, As Plantas de Ricardo de Castel, publicado en Lisboa en 1801 con imágenes producidas por el grabador portugués Eloy de Almeida, clasifica la naturaleza en un relato visual de su dominio por parte del hombre y de la cultura. Sus láminas no eluden, por otra parte, la vocación estética. El libro que la autora analiza, con sus imágenes tomadas de la edición francesa del poema, denota a su vez los fluidos intercambios entre culturas, productoras de imágenes a menudo intercambiables y reutilizadas para contextos $\mathrm{y}$ fines diferentes.

En "Los impresos poblanos efímeros. Una mirada a Tertulia de pulquería, de José A. Arrieta, 1851”, María José Rojas Rendón, considerando una pintura costumbrista del pintor de la ciudad de Puebla, México, compone un análisis del rol de los impresos políticos en las relaciones sociales de los intercambios de clase. A través de la identificación de los periódicos representados en la pintura -de acuerdo con la autora, elementos soslayados en interpretaciones anteriores acerca de la obra- descubre los debates políticos expresados en las hojas periódicas por medio de textos e imágenes. Mediante la exhibición en la pintura analizada de los periódicos, en los cuales las élites manifestaban su discurso contra "los abusos de la libertad de imprenta" y su descalificación de la clase popular como "clase peligrosa", la autora muestra el poder de la prensa y la centralidad de su presencia material en los debates políticos y sociales.

En "El patriotismo del Correo del Domingo: ficciones de guerra y soldados", Candela Marini expone las modalidades en las cuales un periódico ilustrado en Buenos Aires de la década de 1860 desplegó diversas estrategias en el uso de las imágenes y negoció así sentidos culturales y políticos. Desde ellugar de las élites que pretendían actuar como operadores de educación instructiva, dictaminadores de la moral y el gusto estético, el periódico colocó sus recursos en apoyo a la posición oficialista en la guerra de la Triple Alianza contra Paraguay. Las imágenes litográficas del Correo del Domingo, desarrollaron una pluralidad de usos, como el reporte de eventos de actualidad, ilustraciones de la ficción literaria y hasta fines comerciales. En este sentido, la convivencia de funciones diversas devela una de las características de las modalidades de producción visuales de las publicaciones periódicas ilustradas, vinculada con la yuxtaposición de estilos artísticos diferentes y sentidos plurales a menudo bajo un contenido discursivo que se pretendía homogéneo, en este caso la argumentación patriótica oficialista.

La disposición de tecnologías visuales se multiplicó durante el siglo XIX y siguió desarrollándose durante el XX, así lo muestra Ana Bonelli Zapata en "Imagen impresa y ciudad, Buenos Aires (1890-1910)" que pone el foco en las representaciones de la ciudad en avisos de publicidad gráfica publicados 
en distintos medios a fines del siglo XIX en Buenos Aires. El texto presenta la cultura gráfica y sus particularidades a partir del caso específico, se detiene en los clichés publicitarios creados en Gran Bretaña y utiizados en Buenos Aires, hecho que resulta elocuente para analizar las condiciones de producción de la fabricación de imágenes comerciales. Nos dice algo, además, acerca del contexto colonialista y de las relaciones entre América y Europa en ese marco de apropiación eintercambios. Algunas de esas publicidades, vinculan el espacio urbano con los ferrocarriles, una de las insignias de la modernidad y del movimiento que marcaron el espacio y el tiempo de la vida de las ciudades de fines del siglo XIX y representan parte de las imágenes que circularon socialmente en la cultura visual de entresiglos.

Ciudad y gráfica se ponen en relación nuevamente en "Recuerdos de la Gran Aldea. Usos de imágenes del pasado urbano de Buenos Aires 1910-1936" en el cual Catalina Fara describe el modo como las imágenes construyen una representación de un espacio dado, con su vocabulario visual y paisaje, y adquieren particularidades en un momento de la historia urbana que experimentaba significativas transformaciones materiales que impactaron fuertemente en los modos de vida cotidianos. Fara analiza en ese contexto como en diversos objetos impresos, tanto publicaciones periódicas como libros institucionales se utilizaron imágenes del pasado de Buenos Aires. Estos grabados de vistas urbanas del siglo XVIII y comienzos del XIX, y fotografías de fines del siglo XIX, sirvieron a funciones conmemorativas, nostálgicas o celebratorias de un presente transformado y modernizado. Esto produjo una dialéctica visual entre lo nuevo ylo viejo, que configuró los imaginarios de la ciudad moderna produciendo una tensión entre la nostalgia y el progreso y mostrando a las imágenes en el centro de esos intercambios.

En "Imagen impresa y acción social. La decoración del libro al interior del proyecto cultural de Atalaya (1922-1927)" Aldana Villanueva centra su mirada en la figura del crítico cultural Alfredo Chiabra Acosta (Atalaya) y su desarrollo en producción de libros ilustrados con grabados en la década del 20 del siglo XX, proyecto cultural y pedagógico en los que cristalizó sus ideas anarquistas acerca de una práctica artística revolucionaria, anónima y colectiva del arte. Villanueva muestra como el análisis de los libros con grabados permite bucear en las zonas grises entre las llamadas artes mayores y menores. En ese marco Atalaya celebra la producción colectiva y artesanal, ya predicada por William Morris a fines del siglo XIX en Inglaterra de la cual surgieron muchas nociones del diseño gráfico moderno. Del mismo modo, Atalaya concebía al libro como un total armónico, donde debía primar el efecto de conjunto en el que lo visual y lo material conviven en consonancia, y así lo plasmó en los libros económicos de la Biblioteca de la Editorial La Campana de Palo. 
Finalmente, en 'Erotismo y mediatizaciones. Revistas femeninas en la Argentina la década del 60", María Laura Schaufler, expone la densa interacción cultural que las revistas femeninas de los años 60, mantienen con un aspecto que se encontraba en proceso de transformación social en la época: la sexualidad. Percibida por parte de la sociedad como un ataque a la moral consuetudinaria, revistas como Para Ti, Claudia, entremezclaban contenidos de música, política, arte, guerra, erotismo. Los editores de estas publicaciones gráficas encuentran un nuevo objeto al que ofrecer su guía moral, los jóvenes, y hacia allí dirigen sus contenidos.

Estos trabajos en su conjunto, por un lado, afirman el peso social y cultural de la cultura gráfica y a la vez, reclaman mayor atención hacia ese universo que aún presenta zonas sin explorar.

\section{REFERENCIAS}

Chartier, R. (dir.) (1987). Les usages de l’imprimé. París, Fayard.

Chartier, R. y Martin, H. (dirs.) (1989-1991). Histoire de l'édition française, (4 tomos), Paris: Fayard/Promodis.

Darnton, R. ([1979] 2006). El negocio de la Ilustración: Historia editorial de la Encyclopédie, 1775-1800. México: Fondo de Cultura Económica.

Darnton, R. (1990). The Kiss of Lamourette: Reflections in Cultural History. New York: Norton.

Eisenstein, E. ([1979] 2010). La imprenta como agente de cambio. México: Fondo de Cultura Económica.

Gaskell, P. (1998). Nueva introducción a la bibliografía material. Gijón: Trea.

Le Men, S. (1995). La question de l'illustration. En Roger Chartier (dir.), Histoires de la lecture. Un bilan des recherches (pp. 229-247). Paris, IMEC Éditions- Maison des Sciences de l'homme.

Le Men, S. (2002). La Cathédrale illustrée de Hugo à Monet. Regard romantique et modernité. Paris: CNRS.

Nicolajeva, M. y Scott, C. (2006). How Picturebooks Work. New York: Routledge.

Petrucci, A. (1999). Alfabetismo, escritura, sociedad. Barcelona: Gedisa.

Twyman, M. (1994). El surgimiento del libro gráfico en el siglo XIX. En Robin Myers \& Michael Harris (editors). A Millenium of the Book: Production, Design and Illustration in Manuscript and Print, 900-1900 (pp. 135-180). Dellaware: Oak Knoll Press. 
Sandra Szir es Doctora en Teoría e Historia del Arte por la Facultad de Filosofía y Letras de la Universidad de Buenos Aires (UBA), Argentina; Magíster en Sociología de la Cultura y Análisis Cultural por el Instituto de Altos Estudios Sociales de la Universidad Nacional de San Martín (IDAES-UNSAM), Argentina; y Licenciada en Artes por la UBA. Se desempeña como Profesora adjunta en "Teoría e Historiografía delas Artes Plásticas" en la UNSAM y en la UBA. Es profesora de posgrado en la Maestría en Historia del Arte Argentino y Latinoamericano en IDAES-UNSAM. Dirige proyectos de investigación acerca de temas dehistoriografía así como de cultura gráficay visual en la Argentina. Es autora dellibro Infancia y cultura visual. Los periódicos ilustrados para niños (1880-1910) y de otros artículos en libros, publicaciones y congresos de la especialidad. En la actualidad es presidente del Centro Argentino de Investigadores de Arte (CAIA) y dirige la colección "Caleidoscópica” de Comunicación Visual, de la Editorial Ampersand, Buenos Aires, Argentina. 